\title{
REDUCTION OF REFLECTION LOSSES IN SOLAR CELL BY USING TIAL2 AND ZR ANTI REFLECTIVE COATING
}

\author{
S. Anandhi ${ }^{1}$, S. Salomi Mary Magdalene ${ }^{2}$ \\ ${ }^{I}$ Student, Department of Energy Conservation \& Management, University College of Engineering BIT Campus, Anna \\ University, Trichy, TamilNadu, India. \\ ${ }^{2}$ Assistant Professor, Department of EEE, Dhanalakshmi Srinivasan Engineering College, Perambalur, TamilNadu, \\ India.
}

\begin{abstract}
Direct energy conversion from sunlight to electricity is obtained through solar cells. The Efficiency of solar cells is about 23.89\% in the laboratory and 13.76\%. More than 30\% of incident light is reflected back from the surface of single crystalline Silicon (Si) solar cells because of the high refractive index of Silicon material. The initial objective of this project is to minimize the reflection losses in solar cells using an Anti-Reflection coating (ARC). In solar cell applications, a single layer thin film Anti-Reflective coating is often used. But such a Single Layer Anti-Reflective coating (SLARC) and Double layer Anti-Reflective coating reduces reflectivity only in a limited range. Triple Layer Anti-Reflective coatings (TLARC) are so widely utilized to improve conversion efficiencies and current density of silicon solar cells. Such Triple layer anti reflective coating can eliminate the need for a mechanical tracking device for proper optical alignment of the solar cell with respect to incident sunlight.
\end{abstract}

Keywords-ARC, Reflection loss, Solar cell, Reflectance, TiAl2

\section{INTRODUCTION}

Power generation is a leading cause of air pollution and the largest source of global warming emission. The demand for energy is increasing day by day due to heavy industrialization all around the world. But conventional energy sources are failing to meet with this heavy requirement in the power sector. So there is a pressing need to accelerate the development of advanced clean energy technologies. The option is renewable resources like solar, wind, hydro, biomass etc. The world will need greatly increased energy supply in the next 25 years, especially cleanly generated electricity. Electricity demand is increasing overall energy use and is likely to rise $76 \%$ to 2030. Technologies can and must play an integral role in transforming the energy system. Among all non conventional energy resources, Solar cells are considered to the most important and sustainable energy source due to the availability of heavy solar energy. Therefore Solar photovoltaic electricity is a key technology option to realize the shift to a decarbonised energy supply and is projected to emerge as an attractive alternate electricity source in the future. It is the most available energy source which is capable to provide this world's energy needs. The quantity of energy from the sun that arrives at the earth's surface in an hour is about $5100 \mathrm{~J}$ which is more than the total energy consumed by all people of our planet during a year.

Nowadays Anti reflective coatings (ARC) are one of the most read regions of a solar cell since these films improve the efficiency of photovoltaic devices. ARC is a dielectric thin film covering. They are transparent insulating materials put on the supporting material where the circuit is formed. The AR coating prevents reflected waves by using different optical interferences to cancel out the waves through destructive interference.

A large number of different deposition techniques are used for the coating methods in various applications. The wide variety of surface coating techniques available are Physical vapor deposition, Chemical vapor deposition, Thermal spraying, Electro deposition, Electro less deposition, Diffusion coatings, and Laser based techniques [3]. Characteristics of selective coating are

1. The absorption over the solar spectrum (0.3 $2.5 \mu \mathrm{m})$ must be high. The emissivity for wavelength greater than $2.5 \mu \mathrm{m}$ must be low.

2. When humidity changes the properties of the material should not change. The anti reflective coating material is able to withstand the temperature levels. It should stable in vacuum and air. It should withstand atmospheric corrosion and oxidation.

3. The optical and physical properties of the coating must remain stable under the long term operation at elevated temperatures repeated thermal cycling, UV radiations etc.

4. The adherence of the coating to the substrate must be good. The cost of the material should be reasonable.

The reflection losses occur on the top surface of the solar cells, it will reduce the performance of the solar energy generation. The solar energy absorption will reduce in maximum level [5]. 
When the reflection increases than most of the solar energy are wasted or reflected. So it will cause the thermal effect in the solar cell and global warming. In order to avoid such reflection problems, the antireflective coating is used. The reflective coating techniques are important to produce powerful effects of the solar cell. The double layer coating is more advantage than single layer and multilayer antireflective coating [1]. The design process for the single layer is simple since it is not effective. The multilayer design process is complex, but it is a highly effective antireflective coating [1].

\section{MATERIALS AND METHODS}

The TiAl2 and $\mathrm{Zr}$ thin films were prepared by the ceramic type coating technique. The mixture of the Titanium Alumina 40:60 ratio in the solvent. The black colors, solvent absorbed the sunlight and produced electricity at high efficiency output. This TiAl2 and $\mathrm{Zr}$ solvent has applied to the solar cell and dry the solar cell up to $2 \mathrm{~h}$ in the atmospheric condition. The solar cell test on Uncoated has as shown in Fig.1. The Solar Cell Coated for TiAl2 and For $\mathrm{Zr}$ has as shown in the Fig.2and Fig.3. Comparisons to the Uncoated coated have been higher perform in the experiment. In this project the solar cell has tested on Uncoated or without coating in this condition performance of the solar cell has evaluate in the process. After that remove the glass from the solar panel and get the solar cell from the solar panel.

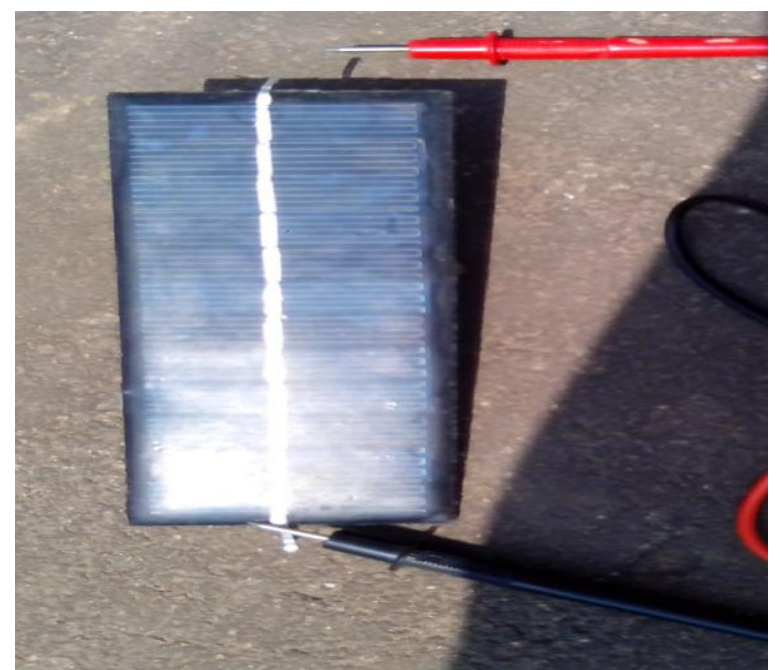

Fig. 1 Uncoated solar cell

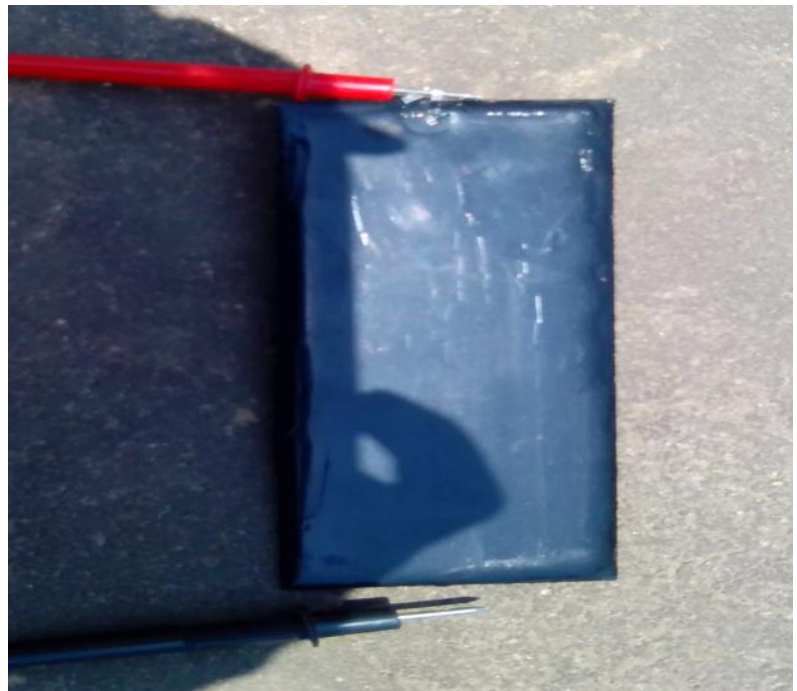

Fig. 2 Coated solar cell for TiAl2

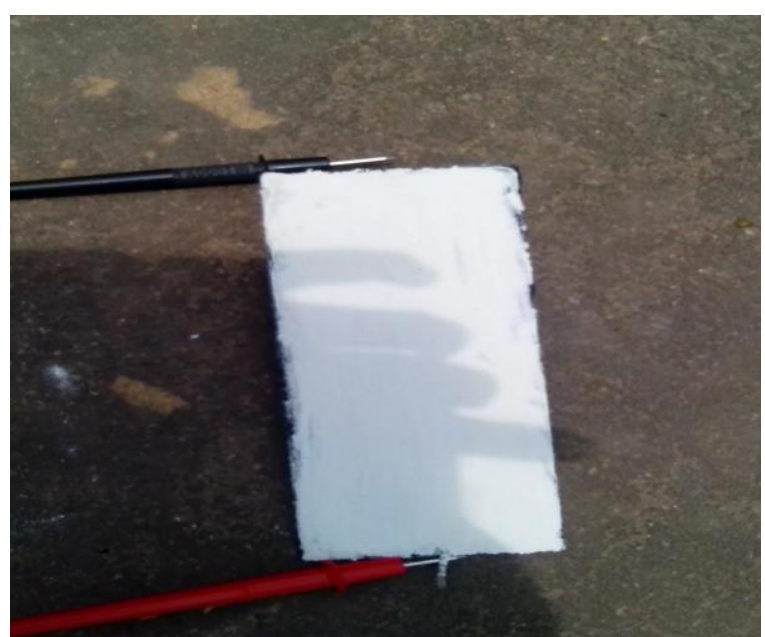

Fig. 3 Coated solar cell for $\mathrm{Zr}$

Apply the solvent solution in solar cell top surface and dry the solar cell up to 2 hours in the atmosphere condition. Repeating to prepare multi-layer structure in the solar cell again dry the solar cell up to 2 hours in the atmosphere condition this way too we will increase the layer of the ARC layers and then finally test the Coated solar cell and analysis the different on Uncoated and coated of the solar cell. The process of methods has as shown in the figure 4.

\begin{tabular}{|c|c|}
\hline \multicolumn{2}{|c|}{ Solar cell test on before coating } \\
\hline \multicolumn{2}{|c|}{ Remove the glass from the solar panel } \\
\hline \multicolumn{2}{|c|}{ Applying the solvent solution in a surface } \\
\hline \multicolumn{2}{|c|}{ Drying } \\
\hline \multicolumn{2}{|c|}{ Repeating to prepare Multilayer structure } \\
\hline \multicolumn{2}{|c|}{ Drying } \\
\hline \multicolumn{2}{|c|}{ Cell Test } \\
\hline $\begin{array}{r}\text { Results: analysis the uncoate } \\
\text { cell }\end{array}$ & d and coated coated solar \\
\hline
\end{tabular}

Fig 4 Flow chart of the process 
The test on Uncoated and coated solar cell in this project the solar cell has tests on before coating or without coating in this condition performance of the solar cell has evaluate in the process. After that remove the glass from the solar panel and get the solar cell from the solar panel and then put the solar cell into the solar cell and record the voltage and current values. Apply the solvent solution in solar cell top surface and dry the solar cell up to 2 hours in the atmosphere condition. Repeating to prepare multi-layer structure in the solar cell again dry the solar cell up to 2 hours in the atmosphere condition. And then put the solar cell in front of the sunlight and recording the voltage and current values in the solar cell and calculate the efficiency of the solar cell.

\section{RESULTS AND DISCUSSION}

The solar cell tested at Anna university, Tiruchirappalli, Tamilnadu state and the solar cell have coated at Spraymet coating industries Bangalore, Karnataka state. The average of the solar cell increased by about $2.62 \%$ and $0.75 \%$ relative, while maintaining the same manufacturing yield. The encapsulated cell parameters are compared in the table 1.

Table 1

\begin{tabular}{|l|l|l|l|l|l|}
\hline $\begin{array}{l}\text { Cell } \\
\text { process }\end{array}$ & $\begin{array}{l}\text { Voc } \\
(\mathbf{V})\end{array}$ & $\begin{array}{l}\text { Isc } \\
(\mathbf{A})\end{array}$ & Power(W) & FF\% & $\begin{array}{l}\text { Efficiency } \\
\text { \% }\end{array}$ \\
\hline UnCoated & 6.4 & 1.1 & 7.04 & 0.268 & 12.78 \\
\hline $\begin{array}{l}\text { Coated } \\
\text { for TiAl2 }\end{array}$ & 7.46 & 1.086 & 8.10 & 0.322 & 15.43 \\
\hline $\begin{array}{l}\text { Coated } \\
\text { for } \mathbf{Z r}\end{array}$ & 6.72 & 1.26 & 7.19 & 0.254 & 13.53 \\
\hline
\end{tabular}

The performance of the uncoated solar cell and coated has as shown in Fig. 5 and 6 and 7. compare to the both coated for $\mathrm{TiAl} 2$ and $\mathrm{Zr}$ and uncoated solar cell performance and efficiency the coated solar cell efficiency has $2.32 \%$ and $0.75 \%$ improved. Time and efficiency of uncoated and coated solar cell performance has as shown in the Fig.9. Finally, here coated solar cell performance increased. The performance Time Vs Efficiency of uncoated and coated solar cell has as shown in Fig.9. the Comparative studies of Uncoated and Coated Solar cell performance has as shown in the fig 8 .

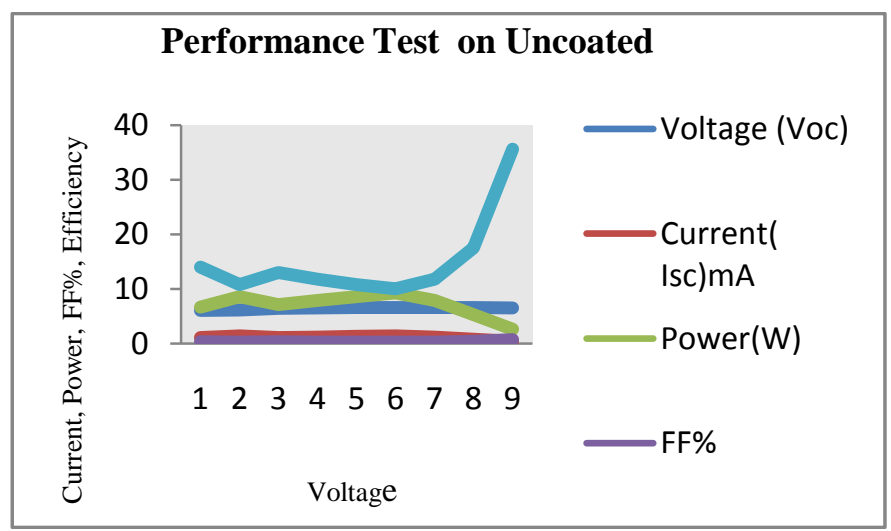

Fig 5 performances of the solar cell tested on uncoated cell

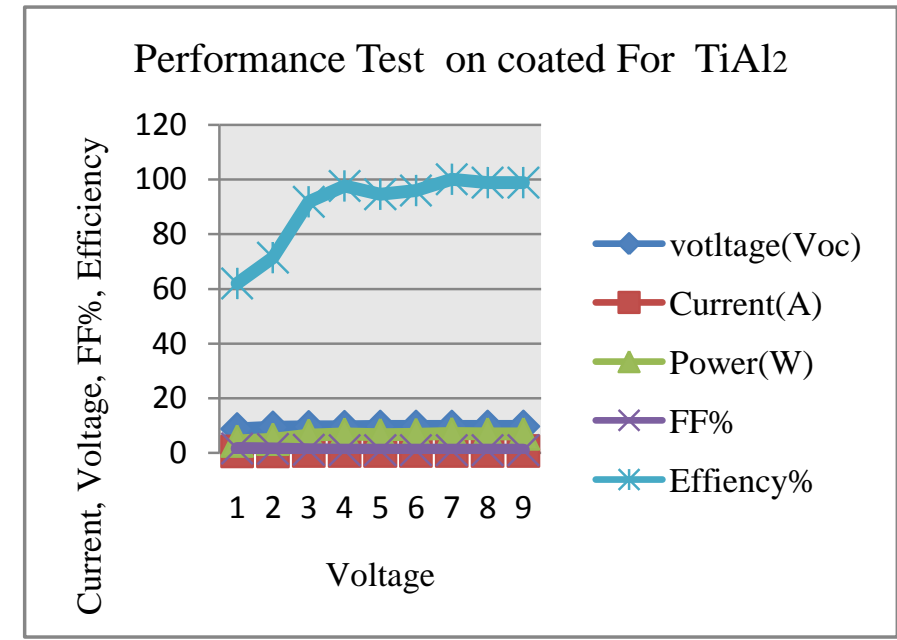

Fig 6 performances of the solar cell tested on coated solar cell for $\mathrm{TiAl} 2$

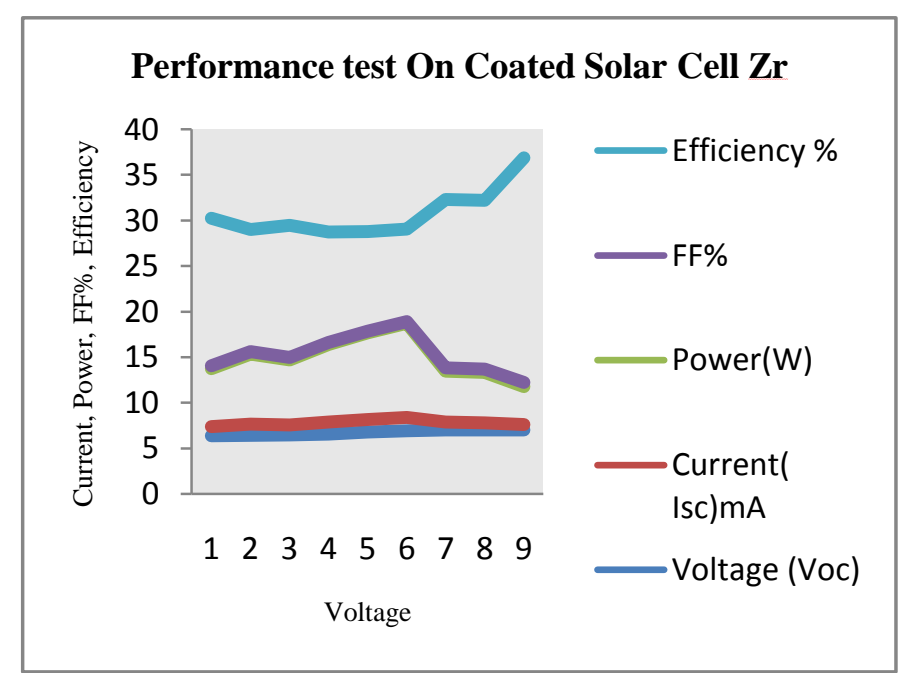

Fig 7 performances of the solar cell tested on coated solar cell for $\mathrm{Zr}$

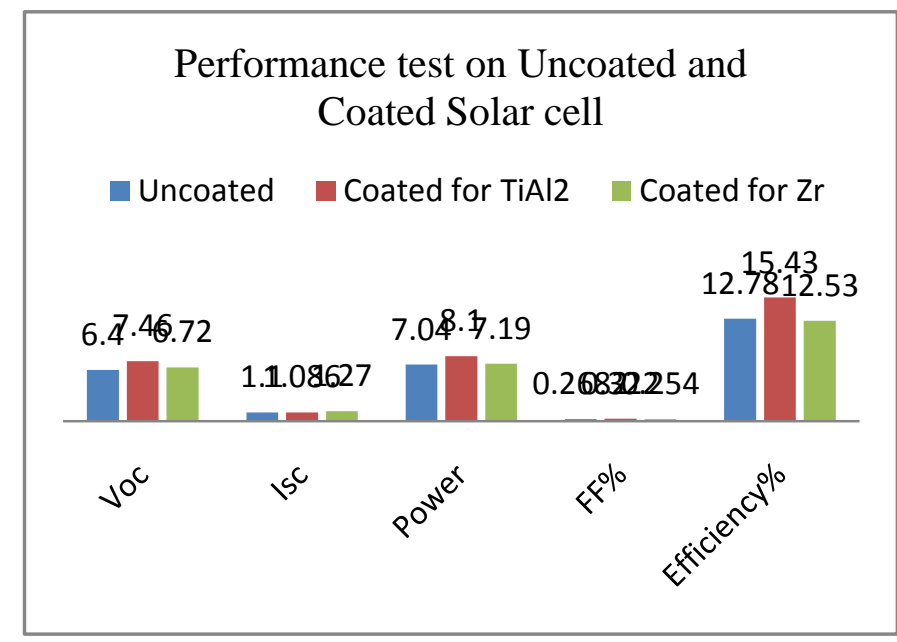

Fig 8 comparative studies of Uncoated and Coated solar cell for $\mathrm{TiAl} 2$ and $\mathrm{Zr}$ 


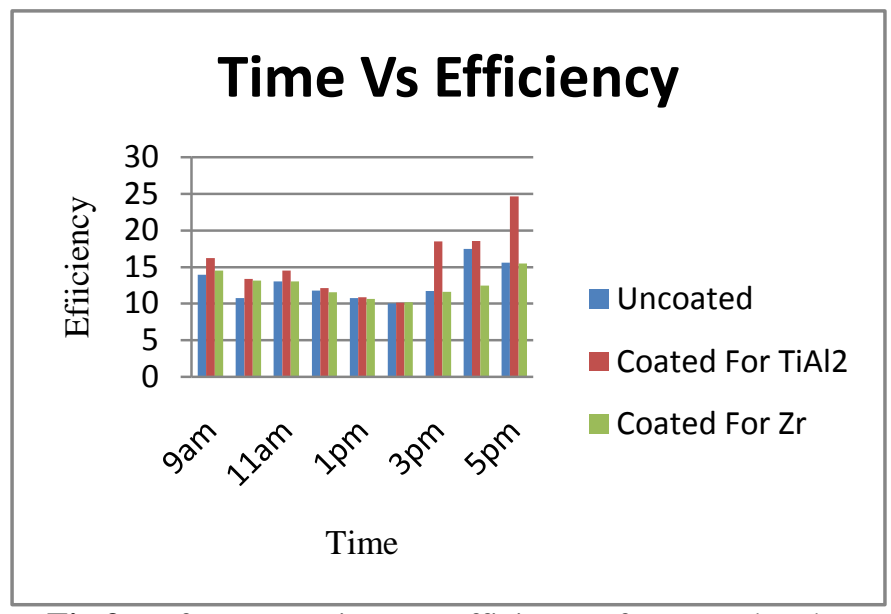

Fig 9 Performance Time Vs Efficiency of uncoated and coated solar cell for TiAl2 and $\mathrm{Zr}$

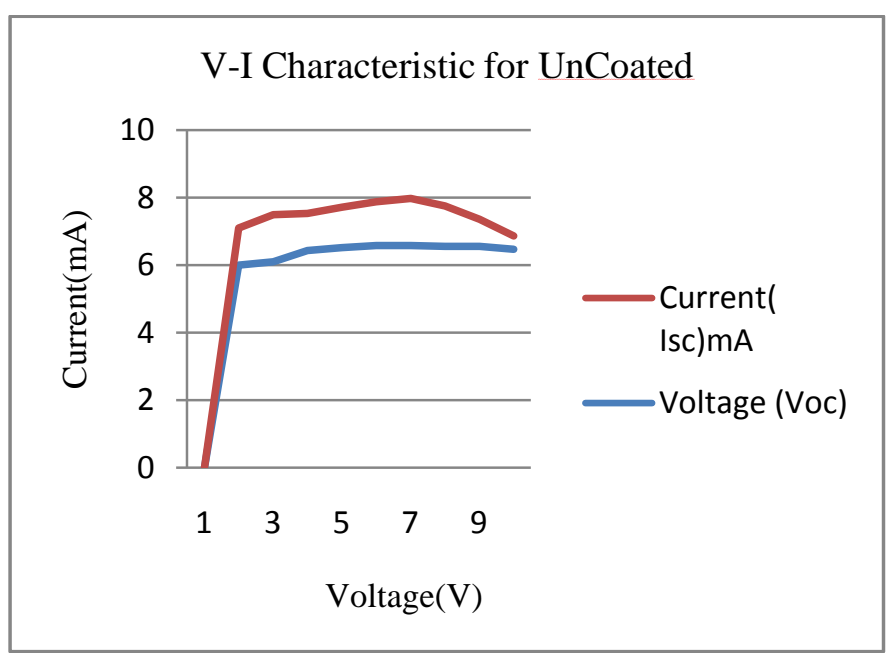

Fig 10 V-I characteristic for uncoated Solar cell

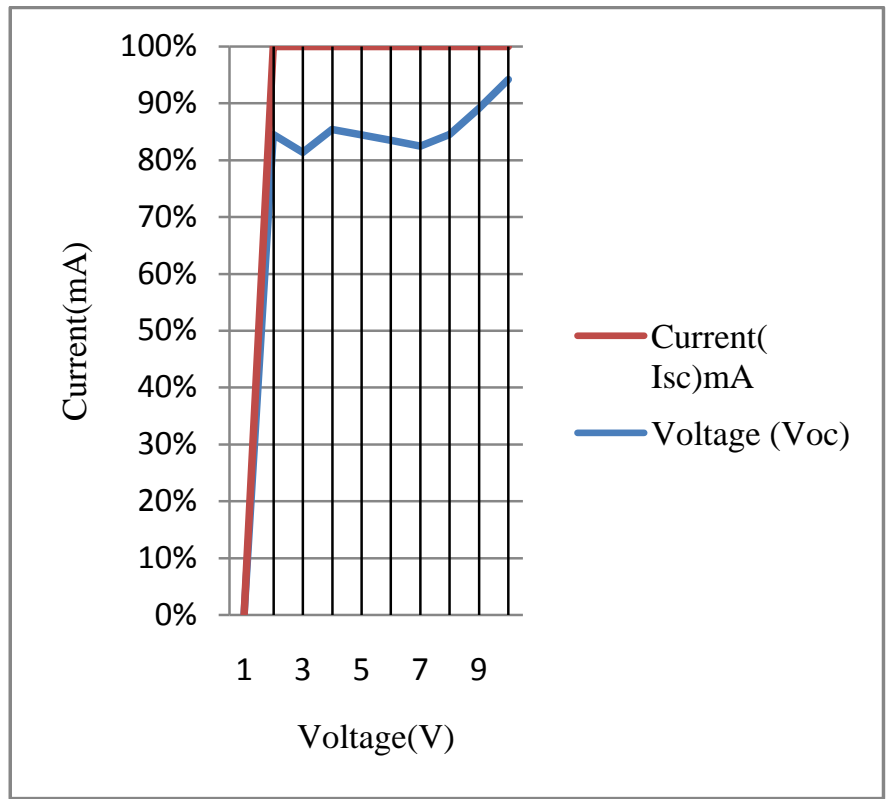

Fig 11 V-I Characteristic of Coated Solar cell for TiAl2

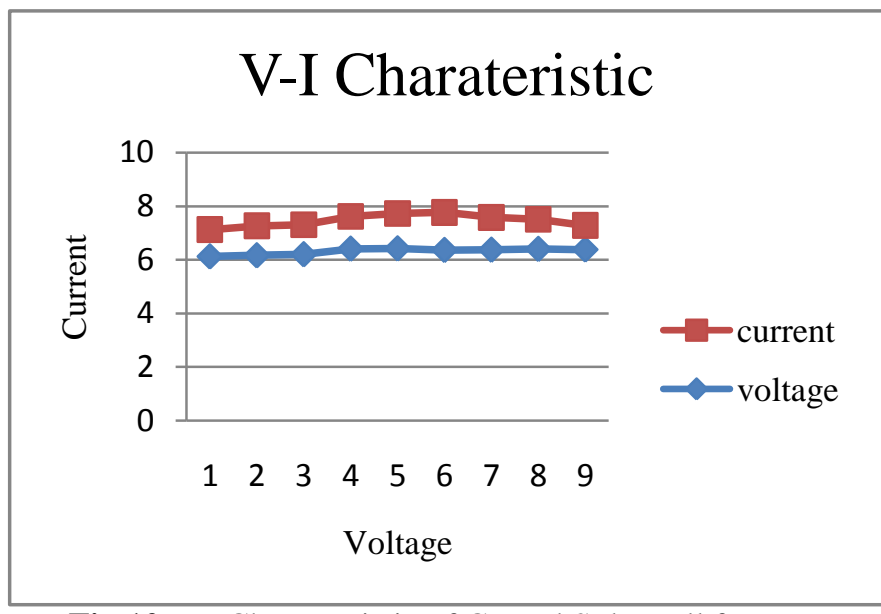

Fig 12 V-I Characteristic of Coated Solar cell for $\mathrm{Zr}$

\section{CONCLUSIONS}

This project concluded the optimum condition for a TiAl2 triple layer AR coating and its influence on improving the conversion efficiency of $\mathrm{Si}$ solar cell. It is illustrated that this triple layer ARC can increase the efficiency $2.34 \%$ of solar cell. Moreover these AR coatings reduce the effect of outdoor soiling and therefore improve the performance of solar systems. The reflectivity of TiAl2 material is very high. The antireflective coatings are used to reduce the reflection loss and increase the efficiency of the solar module. So it is therefore widely utilized to improve the conversion efficiencies of Si solar cells.

\section{REFERENCES}

[1]. A.Ibrahim, A.A.EI-Amin, Etching, Evaporation contacts and antireflection coating on multi-crystalline silicon solar cell V.2 No.3 2012

[2]. Suresh kumar Dhungel, Jinsu Yoo, kyunghane KIM, Sungwook Jung, Somnath Ghosh, Double-Layer Antireflection Coating of MgF2/SiNx for Crystalline Silicon Solar Cells, V.49 no.3 september 2006

[3]. L.A.Dobrzanski, M.Szindler, Sol gel TiO2 antireflection coating for silicon solar cells, V.52 2012

[4]. Bikash kumar, Tim Koval, Srinivasamohan Narayanan and Stephen shea, commercialization of a silicon Nitride co-fire though(SINCOT) process for manufacturing high efficiency mono-crystalline silicon solar cell 1p1.13 2002

[5]. K.T.Roro, N.Tile, B.Yalisi, M.De gama, T.Wittes T.Roberts, A.Forbes, Selective solar absorber coating research at the CSIR (South Africa), 2011

[6]. Daniel N. Wright, Erik S. Marstein and Arve Holt, Double layer Anti-reflective coatings for silicon solar cells 2005

[7]. A.Lennie. H.Abdullah, S.Shaari and K.Sopian, fabrication of single solar layer $\mathrm{SiO} 2$ and $\mathrm{Si} 3 \mathrm{~N} 4$ as Antireflective coating on silicon solar cell using silvaco software ISSN 1546-9239 2009

[8]. Barbara Swatowska, Tomasz Stapinski, Kazimierz Drabczyk, The role of antireflective coatings in silicon solar cells the influence on their electrical parameters V XLI, No.2, 2011 
[9]. Rawmond A. Adomaitis, Alexander Schwarm, System and control challenges in photovoltaic manufacturing processes a modeling strategy for passivation and antireflection films, V.5, 2011

[10]. V.Verlaan, C.H.M.Vander, W.J.Soppe, A.W.Weeber,I.G.Romijn, High efficiency solar cell with passivating Hot wire CVD SiNx coating, V. 32, 2000

[11]. Kyunghae KIM, S.K.Dhungel, J.Yoo, Sungwook Jung, D.Mangalaraj, Hydrogenated silicon- nitride thin film as Antireflection and passivation coating for multicrystalline silicon solar cell, V. 51, No.5, 2007 